\title{
Prognostic Value of p53 and bcl-2 Expression in Patients Treated with Breast Conservative Therapy
}

Prognostic value of p53 and bcl-2 expression on treatment outcome in breast cancer patients has been extensively evaluated, but the results were inconclusive. We evaluated the prognostic significance of these molecular markers in patients treated with breast conserving surgery and radiotherapy. One hundred patients whose immunostaining of p53 and bcl-2 expression was available among 125 patients who underwent radiotherapy after breast conserving surgery and axillary lymph node dissection were enrolled into this study. Eighty-seven patients also received adjuvant chemotherapy and/or hormonal therapy. Conventional clinicopathologic variables and treatment-related factors were also considered. The 5-yr loco-regional relapse-free and distant metastasis-free survival rates were $91.7 \%$ and $90.9 \%$, respectively. On univariate analysis, age, T stage and the absence of bcl-2 \& estrogen receptor (ER) expression were associated with loco-regional relapse-free survival. When incorporating these variables into Cox proportional hazard model, only $\mathrm{bcl}-2(-) / E R(-)$ phenotype was an adverse prognostic factor $(P=0.018)$. As for the distant metastasis-free survival, age, $T$ stage, and p53 expression were significant on univariate analysis. However, p53 expression was the only prognosticator on multivariate analysis ( $P=0.009)$. A bcl-2(-)/ER(-) phenotype and p53 expression are useful molecular markers predicting loco-regional relapse-free and distant metastasis-free survival, respectively, in patients treated with breast conserving surgery and radiotherapy.

Key Words : Breast Neoplasms; bcl-2; p53

(C) 2010 The Korean Academy of Medical Sciences.

This is an Open Access article distributed under the terms of the Creative Commons Attribution Non-Commercial License (http://creativecommons.org/licenses/by-nc/3.0) which permits unrestricted non-commercial use, distribution, and reproduction in any medium, provided the original work is properly cited.

\author{
Kyubo Kim', Eui Kyu Chie', \\ Wonshik Han', Dong-Young Noh², \\ In Ae Park ${ }^{3}$, Do-Youn $\mathrm{Oh}^{4}$, \\ Seock-Ah Im ${ }^{4}$, Tae-You Kim \\ Yung-Jue Bang ${ }^{4}$, and Sung W. $\mathrm{Ha}^{1,5}$ \\ Departments of Radiation Oncology', Surgery², \\ Pathology ${ }^{3}$, and Internal Medicine ${ }^{4}$, Seoul National \\ University College of Medicine; Institute of Radiation \\ Medicine ${ }^{5}$, Medical Research Center, Seoul National \\ University, Seoul, Korea \\ K Kim and EK Chie contributed equally to this study.
}

Received : 4 February 2009

Accepted : 27 April 2009

Address for Correspondence

Sung W. Ha, M.D.

Department of Radiation Oncology, Seoul National

University College of Medicine, 103 Daehak-ro,

Jongno-gu, Seoul 110-744, Korea

Tel : +82.2-2072-2524, Fax : +82.2-765-3317

E-mail : swha@snu.ac.kr

Presented at the 49th Annual Meeting of the American Society for Therapeutic Radiology and Oncology, Los Angeles, CA USA Oct 27-Nov 1, 2007.

\section{INTRODUCTION}

Nodal involvement and tumor size are the most important prognostic factors for breast cancer patients at different risk of disease recurrence and/or death (1). Many clinicopathologic variables other than TNM stage have been identified to predict the clinical course of the disease. However, identifying all high-risk patients is still difficult. Beyond the conventional clinicopathologic variables, therefore, novel prognostic factors are needed to be explored to predict the outcome more accurately (2). Molecular markers such as p53 and bcl-2 have been extensively evaluated for their prognostic value since the 1990s (2-5). Although the prognostic value of $\mathrm{p} 53$ and bcl-2 expression in breast cancer has been evaluated in a number of studies, the results were controversial. Heterogeneous patient and tumor characteristics might be partly responsible for the discrepancy. Treatments were also various with mastectomy $(6,7)$ breast conservative therapy
(8-11) or the combination of the two (12-14).

Given these observations, we evaluated the prognostic value of p53 and bcl-2 expression on the treatment outcome, in relatively homogeneous population consisted of early stage breast cancer patients who underwent breast conservative treatment. In addition, the correlation between these markers and triple-negative phenotype was also investigated.

\section{MATERIALS AND METHODS}

Between March 2000 and February 2002, 125 patients underwent radiotherapy after breast conserving surgery for breast cancer. Of these, 100 patients whose immunohistochemical staining for $\mathrm{p} 53$ and bcl-2 was performed at the time of diagnosis were the cohorts for this retrospective study.

The median age was $44 \mathrm{yr}$ (range; 24-68). Performance status of the patients was good with ECOG grade of 0 for 
27 patients and grade of 1 for 73 patients. Histologic subtype was invasive ductal carcinoma in 90 patients $(90.0 \%)$.

All patients had breast conserving surgery with axillary lymph node dissection. Sixty patients received chemotherapy: cyclophosphamide, methotrexate and 5-fluorouracil in 30 patients; doxorubicin-containing regimen in 27 patients; others in 3 patients. Sixty-two patients received hormonal therapy and 35 of them also received chemotherapy. As regards to radiotherapy, whole breast irradiation was given, up to $50.4 \mathrm{~Gy}$ at $1.8 \mathrm{~Gy} /$ fraction by using two opposing tangential photon beams. Tumor bed boost was supplemented up to $10 \mathrm{~Gy}$ at $2 \mathrm{~Gy} /$ fraction.

The clinicopathologic findings according to the expression of $\mathrm{p} 53$ and bcl-2 are summarized in Table 1. Median duration of follow-up was 69 months (range; 21-88).

The specimens were immunostained to determine the expression of $\mathrm{p} 53$, bcl-2 and c-erbB2 as well as the status of estrogen receptor (ER) and progesterone receptor (PR). Immunostaining was performed in the usual manner, using antibodies to p53 (Dako, Glostrup, Denmark; 1:1,200), bcl-2 (Dako, 1:50), c-erbB2 (Novacastra Laboratories Ltd., New Castle upon Tyne, UK, 1:200), ER (Dako, 1:50) and PR (Dako, 1:50).

The percentage of tumor cells with nuclear staining for p53 was graded semi-quantitatively: 0\%, 1-25\%, 26-50\%,

Table 1. Clinicopathologic variables according to the expression of p53 and bcl-2

\begin{tabular}{|c|c|c|c|c|c|c|}
\hline \multirow[b]{2}{*}{ Variables } & \multicolumn{2}{|c|}{ No. of patients } & \multirow{2}{*}{$P$} & \multicolumn{2}{|c|}{ No. of patients } & \multirow{2}{*}{$\begin{array}{c}S^{S} \\
\text { value }\end{array}$} \\
\hline & $\begin{array}{c}\text { p53 } \\
(+)\end{array}$ & $\begin{array}{c}\text { p53 } \\
(-)\end{array}$ & & $\begin{array}{c}\text { bcl-2 } \\
(+)\end{array}$ & $\begin{array}{c}\text { bcl-2 } \\
(-)\end{array}$ & \\
\hline \multicolumn{7}{|l|}{ Age } \\
\hline$<40 \mathrm{yr}$ & 7 & 15 & $0.741^{*}$ & 17 & 5 & $0.765^{\star}$ \\
\hline$\geq 40 \mathrm{yr}$ & 22 & 56 & & 63 & 15 & \\
\hline \multicolumn{7}{|l|}{ Tumor size } \\
\hline$\leq 2 \mathrm{~cm}$ & 19 & 51 & $0.531^{\star}$ & 54 & 16 & $0.275^{\dagger}$ \\
\hline$>2 \mathrm{~cm}$ & 10 & 20 & & 26 & 4 & \\
\hline \multicolumn{7}{|c|}{ Nodal involvement } \\
\hline Negative & 17 & 58 & $0.015^{\star}$ & 58 & 17 & $0.248^{\dagger}$ \\
\hline Positive & 12 & 13 & & 22 & 3 & \\
\hline \multicolumn{7}{|c|}{ Estrogen receptor } \\
\hline Negative & 12 & 13 & $0.015^{*}$ & 11 & 14 & $<0.001^{*}$ \\
\hline Positive & 17 & 58 & & 69 & 6 & \\
\hline \multicolumn{7}{|c|}{ Progesterone receptor } \\
\hline Negative & 19 & 37 & $0.220^{*}$ & 38 & 18 & $<0.001^{\dagger}$ \\
\hline Positive & 10 & 34 & & 42 & 2 & \\
\hline \multicolumn{7}{|l|}{ c-erbB2 } \\
\hline Negative & 20 & 55 & $0.373^{*}$ & 62 & 13 & $0.248^{*}$ \\
\hline Positive & 9 & 16 & & 18 & 7 & \\
\hline \multicolumn{7}{|c|}{ Triple negative } \\
\hline Yes & 10 & 9 & $0.011^{\star}$ & 8 & 11 & $<0.001^{\dagger}$ \\
\hline No & 19 & 62 & & 72 & 9 & \\
\hline \multicolumn{7}{|l|}{ bcl-2 } \\
\hline Negative & 11 & 9 & $0.004^{*}$ & - & - & - \\
\hline Positive & 18 & 62 & & & & \\
\hline
\end{tabular}

${ }^{*}$ chi-square test; ${ }^{\dagger}$ Fisher's exact test.
$51-75 \%$ or $>75 \%$. For statistical analysis, p 53 expression was considered as negative if $\leq 25 \%$ of tumor cells were stained and as positive if $>25 \%$ of tumor cells were stained. ER/PR and bcl-2 expression were judged as positive when $\geq 10 \%$ of tumor cells were stained in nucleus and membrane, respectively. C-erbB2 expression was considered as positive if the score was 3, and negative if the score was 0,1 or 2 .

Statistical analysis was done by using SPSS software (release 12.0.1. SPSS Inc., Chicago, IL, USA). Differences in categorical variables between the parameters were compared by using standard chi-square test or Fisher's exact test. The actuarial survival rates were calculated by using the Kaplan-Meier method and statistical significance of differences between the actuarial survival rates was evaluated by the log-rank test. Cox proportional hazard model was used for multivariate analysis. For all statistical tests, $P$ values $<0.05$ were considered significant.

\section{RESULTS}

Patients with p53 expression were more likely to have node-positive and ER-negative tumors. In contrast, bcl-2 expression was associated with both ER- and PR-positivity. Expression of p53 was correlated with triple-negative phenotype $(P=0.011)$, while bcl-2 negativity was correlated with triple-negative phenotype $(P<0.001)$. Inverse relationship was demonstrated between p53 and bcl-2 expression ( $P=0.004$, Table 1$)$.

The 5-yr loco-regional relapse-free and distant metastasisfree survival rates were $91.7 \%$ and $90.9 \%$, respectively. On univariate analysis, age less than $40 \mathrm{yr}$ and T2 stage were significant prognosticators predicting poor loco-regional relapsefree survival (Table 2). When incorporating these variables into Cox proportional hazard model, however, both lost the statistical significance. Given the association between bcl-2 expression and ER status, we tested interaction of the two variables. Compared with bcl-2(-)/ER(-) phenotype $(n=14)$, other phenotypes (bcl-2[-]/ER[+], bcl-2[+]/ER[-], and bcl$2[+] / \mathrm{ER}[+])$ achieved higher loco-regional relapse-free survival rate $(77.9 \%$ vs. $93.9 \%, P=0.033$, Fig. 1$)$. On multivariate analysis incorporating age, $\mathrm{T}$ stage and the presence of bcl2(-)/ER(-) phenotype, the bcl-2(-)/ER(-) phenotype was the only adverse prognostic factor for loco-regional relapse-free survival $(P=0.018)$. When the use of chemotherapy and hormonal therapy were added in the model, the prognostic significance of the bcl-2(-)/ER(-) phenotype became marginal $(P=0.064)$.

For the distant metastasis-free survival, age less than $40 \mathrm{yr}$, T2 stage and p53 positivity (Fig. 2) were adverse prognostic factors (Table 2). Patients with bcl-2(-)/ER(-) phenotype had an inferior distant metastasis-free survival rate than those with other phenotypes, but the difference was not statistically significant $(77.9 \%$ vs. $93.0 \%, P=0.153)$. On multivariate anal- 
Table 2. Univariate and multivariate analysis for 5-yr loco-regional relapse-free and distant metastasis-free survival rate

\begin{tabular}{|c|c|c|c|c|c|c|}
\hline \multirow{2}{*}{ Variables } & \multirow{2}{*}{$\begin{array}{c}\text { 5-yr } \\
\text { LRRFS }\end{array}$} & \multicolumn{2}{|c|}{$P$ value } & \multirow{2}{*}{$\begin{array}{c}\text { 5-yr } \\
\text { DMFS }\end{array}$} & \multicolumn{2}{|c|}{$P$ value } \\
\hline & & Uni & Multi & & Uni & Multi \\
\hline \multicolumn{7}{|l|}{ Age } \\
\hline$<40 \mathrm{yr}$ & $80.6 \%$ & 0.032 & 0.081 & $77.3 \%$ & 0.033 & 0.123 \\
\hline$\geq 40 \mathrm{yr}$ & $94.7 \%$ & & & $94.8 \%$ & & \\
\hline \multicolumn{7}{|l|}{ Tumor size } \\
\hline$\leq 2 \mathrm{~cm}$ & $95.7 \%$ & 0.046 & 0.068 & $97.1 \%$ & 0.002 & 0.061 \\
\hline$>2 \mathrm{~cm}$ & $82.6 \%$ & & & $76.7 \%$ & & \\
\hline \multicolumn{7}{|c|}{ Nodal involvement } \\
\hline Negative & $94.7 \%$ & 0.110 & - & $94.6 \%$ & 0.076 & 0.452 \\
\hline Positive & $82.8 \%$ & & & $80.0 \%$ & & \\
\hline \multicolumn{7}{|c|}{ Estrogen receptor } \\
\hline Negative & $93.0 \%$ & 0.347 & - & $93.3 \%$ & 0.323 & 0.852 \\
\hline Positive & $87.6 \%$ & & & $83.4 \%$ & & \\
\hline \multicolumn{7}{|c|}{ Progesterone receptor } \\
\hline Negative & $92.8 \%$ & 0.650 & - & $95.5 \%$ & 0.498 & - \\
\hline Positive & $90.7 \%$ & & & $87.2 \%$ & & \\
\hline \multicolumn{7}{|l|}{ p53 } \\
\hline Negative & $94.2 \%$ & 0.181 & - & $97.1 \%$ & $<0.001$ & 0.009 \\
\hline Positive & $86.2 \%$ & & & $75.9 \%$ & & \\
\hline \multicolumn{7}{|l|}{$\mathrm{bcl}-2$} \\
\hline Negative & $84.0 \%$ & 0.140 & - & $78.7 \%$ & 0.099 & - \\
\hline $\begin{array}{l}\text { Positive } \\
\text { c-erbB2 }\end{array}$ & $93.5 \%$ & & & $93.8 \%$ & & \\
\hline Negative & $90.3 \%$ & 0.423 & - & $91.9 \%$ & 0.359 & - \\
\hline Positive & $96.0 \%$ & & & $88.0 \%$ & & \\
\hline \multicolumn{7}{|c|}{ Bcl-2(-)/ER(-) } \\
\hline Yes & $77.9 \%$ & 0.033 & 0.018 & $77.9 \%$ & 0.153 & - \\
\hline No & $93.9 \%$ & & & $93.0 \%$ & & \\
\hline \multicolumn{7}{|c|}{ Triple negative } \\
\hline Yes & $89.2 \%$ & 0.620 & - & $78.6 \%$ & 0.107 & - \\
\hline No & $92.3 \%$ & & & $93.8 \%$ & & \\
\hline
\end{tabular}

LRRFS, loco-regional relapse-free survival; DMFS, distant metastasisfree survival; ER, estrogen receptor.

ysis incorporating aforementioned variables as well as nodal and ER status, which were correlated with $\mathrm{p} 53$ expression, only p53 expression was significant $(P=0.009)$. The statistical significance of $\mathrm{p} 53$ expression remained even after the use of chemotherapy and hormonal therapy were added in the model $(P=0.011)$.

In subgroup analysis with triple-negative phenotype $(\mathrm{n}=$ 19), bcl-2(-)/ER(-) phenotype was not associated with locoregional relapse $(P=0.204)$, and $\mathrm{p} 53$ expression was not associated with distant metastasis $(P=0.331)$.

\section{DISCUSSION}

There have been several reports that investigated the prognostic value of $\mathrm{p} 53$ or bcl-2 expression on loco-regional failure after breast conservative therapy. Elkhuizen et al. compared 66 patients who experienced local recurrence with 139 matched controls in terms of the expression of several onco-

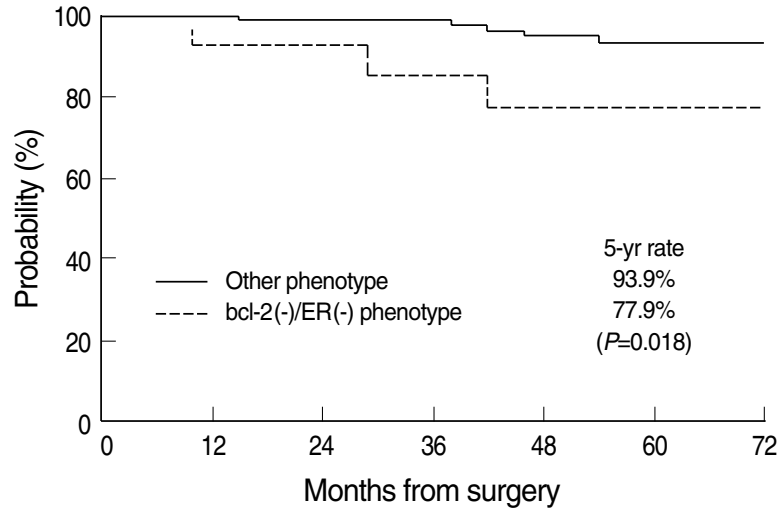

Fig. 1. Loco-regional relapse-free survival curves according to the expression of bcl-2(-)/ER(-) phenotype.

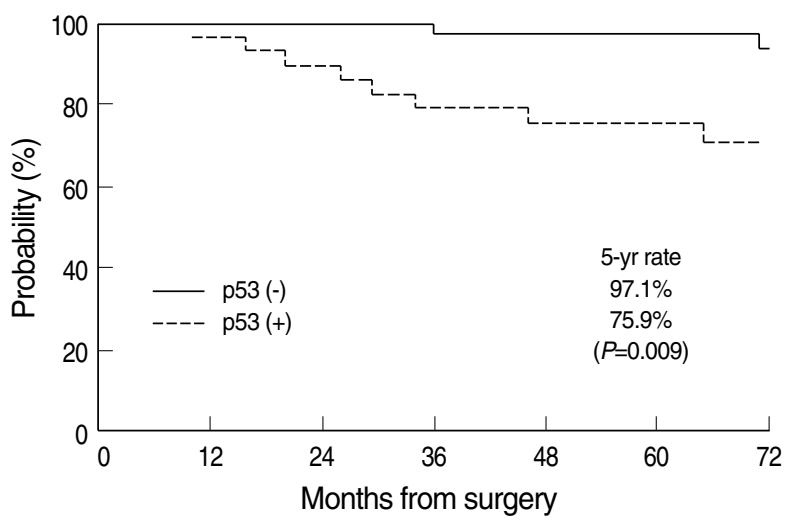

Fig. 2. Distant metastasis-free survival curves according to the expression of p53.

genes along with histological factors. They found that bcl-2 negativity carried a 17 times higher risk of local recurrence in patients $>50 \mathrm{yr}$ (10). Noguchi et al. (9) and Turner et al. (15) conducted similar case-control studies and noted the association between local recurrence and $\mathrm{p} 53$ positivity. However, a case-control approach has the limitation of inevitable biases in selecting control cases although the process is random. In contrast, other studies which analyzed consecutive patients failed to show any prognostic significance of these markers on local control $(8,11,16)$. This might be partly due to the small number of events, that is, local recurrences in early stage breast cancer patients receiving breast conservative therapy.

We also failed to show that any of the two molecular markers was associated with loco-regional relapse-free survival. Instead, the combined variable of bcl-2(-)/ER(-) phenotype was proven to be a significant prognostic factor in univariate and multivariate analyses. Given the association between bcl2 expression and ER status in a number of studies including ours (11, 17-19), a combined analysis of bcl-2 and ER has already been tried. Callagy et al. showed that the risk of death in bcl-2(-)/ER(-) phenotype is higher than those in other three phenotypes (20). Gasparini et al. demonstrated that the bcl- 
2(-)/ER(-) phenotype had a 5.7 times higher risk of overall recurrence compared with bcl-2(+)/ER(-) phenotype on multivariate analysis (12). Likewise, an analysis of several molecular markers in combination provides more accurate prognostic information than that of the single variable, even in the low-risk group like our population.

For the distant metastasis, there are some limited data on the prognostic value of these markers in the breast conservative treatment setting. Aforementioned case-control studies noted a higher risk of distant metastases in patients with $\mathrm{p} 53$ expression $(9,15)$. Again, however, consecutive populationbased studies failed to verify the relationship, despite the larger number of patients and events $(11,17)$. In the current study, p53 positivity was an independent prognostic factor predicting distant metastasis-free survival after adjusting conventional clinicopathologic variables including nodal and ER status and treatment-related factors such as the use of chemotherapy and/or hormonal therapy.

Recently, a number of investigators are seeking for new therapeutic strategy for triple-negative breast cancer, which is associated with inferior distant metastasis-free survival (2123). Unlike other reports, however, triple negativity was not a significant risk factor for distant metastasis in the present study. However, the correlation between p53 expression and triple-negative phenotype was demonstrated. This finding was also observed by other studies $(24,25)$. Although the prognostic impact of $\mathrm{p} 53$ expression in triple-negative tumors was not established in our study as well as others (25), p53 expression can give therapeutic implication for those patients with triple-negative tumors. Regarding this issue, Bidard et al. showed that the rate of pathologic complete remission was higher in patients with $\mathrm{p} 53$-positive tumors than those with $\mathrm{p} 53$-negative tumors after neoadjuvant chemotherapy for triple-negative breast cancer (26).

Despite the small number of patients and events, our study demonstrated the prognostic significance of bcl-2 and p53 expression on loco-regional control and distant metastasis, respectively. This is partly because our population is relatively homogeneous, consisted of early stage breast cancer patients treated with breast conserving surgery and radiotherapy. Moreover, accrual period of the patient was relatively short, and therefore our patients were treated in a relatively uniform fashion regarding loco-regional therapy. But, the delivery of systemic therapy was somewhat various as decision to undergo systemic therapy was based on the risk of the individual patient and the subsequent gain with systemic therapy. Further studies with larger population are needed to confirm the results from this study.

Unlike hormonal receptor expression or c-erbB2 expression, there is currently no specific treatment available to target tumors with either $\mathrm{p} 53$ expression or bcl-2 negativity. But, breast cancer patients may be stratified into more detailed subtypes by these markers as well as other more relevant molecular markers, which are in the process of development.
Although more diversified patient and tumor specific treatment strategies need to be elucidated from future trials, this approach will eventually benefit patients undergoing treatment for breast cancer.

In conclusion, results from this study show that a bcl-2(-)/ ER(-) phenotype and $\mathrm{p} 53$ positivity are useful molecular markers predicting loco-regional relapse-free and distant metastasis-free survival, respectively, in patients treated with breast conserving surgery and radiotherapy.

\section{REFERENCES}

1. Cianfrocca M, Goldstein LJ. Prognostic and predictive factors in early-stage breast cancer. Oncologist 2004; 9: 606-16.

2. Alizadeh AA, Ross DT, Perou CM, van de Rijn M. Towards a novel classification of human malignancies based on gene expression patterns. J Pathol 2001; 195: 41-52.

3. Thor AD, Moore DH II, Edgerton SM, Kawasaki ES, Reihsaus E, Lynch HT, Marcus JN, Schwartz L, Chen LC, Mayall BH, Smith HS. Accumulation of p53 tumor suppressor gene protein: an independent marker of prognosis in breast cancers. J Natl Cancer Inst 1992; 84: 845-55.

4. Bergh J, Norberg T, Sjogren S, Lindgren A, Holmberg L. Complete sequencing of the p53 gene provides prognostic information in breast cancer patients, particularly in relation to adjuvant systemic therapy and radiotherapy. Nat Med 1995; 1: 1029-34.

5. Silvestrini R, Veneroni S, Daidone MG, Benini E, Boracchi P, Mezzetti M, Di Fronzo G, Rilke F, Veronesi U. The Bcl-2 protein: a prognostic indicator strongly related to 53 protein in lymph node-negative breast cancer patients. J Natl Cancer Inst 1994; 86: 499-504.

6. Zhang GJ, Tsuda H, Adachi I, Fukutomi T, Yamamoto H, Hirohashi S. Prognostic indicators for breast cancer patients with one to three regional lymph node metastases, with special reference to alterations in expression levels of bcl-2, p53 and c-erbB-2 proteins. Jpn J Clin Oncol 1997; 27: 371-7.

7. Chen HH, Su WC, Guo HR, Chang TW, Lee WY.p53 and c-erbB2 but not bcl-2 are predictive of metastasis-free survival in breast cancer patients receiving post-mastectomy adjuvant radiotherapy in Taiwan. Jpn J Clin Oncol 2002; 32: 332-9.

8. Silvestrini R, Veneroni S, Benini E, Daidone MG, Luisi A, Leutner M, Maucione A, Kenda R, Zucali R, Veronesi U. Expression of p53, glutathione S-transferase-pi and Bcl-2 proteins and benefit from adjuvant radiotherapy in breast cancer. J Natl Cancer Inst 1997; 89: 63945.

9. Noguchi S, Koyama H, Kasugai T, Tsukuma H, Tsuji N, Tsuda H, Akiyama F, Motomura K, Inaji H. A case-control study on risk factors for local recurrences of distant metastases in breast cancer patients treated with breast-conserving surgery. Oncology 1997; 54: 46874.

10. Elkhuizen PH, Voogd AC, van den Broek LC, Tan IT, van Houwelingen HC, Leer JW, van de Vijver MJ. Risk factors for local recurrence after breast-conserving therapy for invasive carcinomas: a case-control study of histological factors and alterations in oncogene expres- 
sion. Int J Radiat Oncol Biol Phys 1999; 45: 73-83.

11. Choi DH, Kim S, Rimm DL, Carter D, Haffty BG. Immunohistochemical biomarkers in patients with early-onset breast carcinoma by tissue microarray. Cancer J 2005; 11: 404-11.

12. Gasparini G, Barbareschi M, Doglioni C, Palma PD, Mauri FA, Boracchi P, Bevilacqua P, Caffo O, Morelli L, Verderio P, Pezzella F, Harris AL. Expression of bcl-2 protein predicts efficacy of adjuvant treatments in operable node-positive breast cancer. Clin Cancer Res 1995; 1: 189-98.

13. Lê MG, Mathieu MC, Douc-Rasy S, Le Bihan ML, Adb El All H, Spielmann M, Riou G. c-myc, p53 and bcl-2, apoptosis-related genes in infiltrating breast carcinomas: evidence of a link between bcl-2 protein over-expression and a lower risk of metastasis and death in operable patients. Int J Cancer 1999; 84: $562-7$.

14. Neri A, Marrelli D, Roviello F, DeMarco G, Mariani F, DeStefano A, Megha T, Caruso S, Corso G, Cioppa T, Pinto E. Bcl-2 expression correlates with lymphovascular invasion and long-term prognosis in breast cancer. Breast Cancer Res Treat 2006; 99: 77-83.

15. Turner BC, Gumbs AA, Carbone CJ, Carter D, Glazer PM, Haffty BG. Mutant p53 protein overexpression in women with ipsilateral breast tumor recurrence following lumpectomy and radiation therapy. Cancer 2000; 88: 1091-8.

16. Kim KJ, Huh SJ, Yang JH, Park W, Nam SJ, Kim JH, Lee JH, Kang SS, Lee JE, Kang MK, Park YJ, Nam HR. Treatment results and prognostic factors of early breast cancer treated with a breast conserving operation and radiotherapy. Jpn J Clin Oncol 2005; 35: 126-33.

17. Rolland P, Spendlove I, Madjid Z, Rakha EA, Patel P, Ellis IO, Durrant L. The 553 positive Bcl-2 negative phenotype is an independent marker of prognosis in breast cancer. Int J Cancer 2007; 120: 1311-7.

18. Hellemans P, van Dam PA, Weyler J, van Oosterom AT, Buytaert $\mathrm{P}$, van Marck E. Prognostic value of bcl-2 expression in invasive breast cancer. Br J Cancer 1995; 72: 354-60.
19. Berardo MD, Elledge RM, de Moor C, Clark GM, Osborne CK, Allred DC. Bcl-2 and apoptosis in lymph node positive breast carcinoma. Cancer 1998; 82: 1296-302.

20. Callagy GM, Pharoah PD, Pinder SE, Hsu FD, Nielsen TO, Ragaz $\mathrm{J}$, Ellis IO, Huntsman D, Caldas C. Bcl-2 is a prognostic marker in breast cancer independently of the Nottingham Prognostic Index. Clin Cancer Res 2006; 12: 2468-75.

21. Haffty BG, Yang Q, Reiss M, Kearney T, Higgins SA, Weidhaas J, Harris L, Hait W, Toppmeyer D. Locoregional relapse and distant metastasis in conservatively managed triple negative early-stage breast cancer. J Clin Oncol 2006; 24: 5652-7.

22. Nguyen PL, Taghian AG, Katz MS, Niemierko A, Abi Raad RF, Boon WL, Bellon JR, Wong JS, Smith BL, Harris JR. Breast cancer subtype approximated by estrogen receptor, progesterone receptor, and HER-2 is associated with local and distant recurrence after breast-conserving therapy. J Clin Oncol 2008; 26: 2373-8.

23. Freedman GM, Anderson PR, Li T, Nicolaou N. Locoregional recurrence of triple-negative breast cancer after breast-conserving surgery and radiation. Cancer 2009; 115: 946-51.

24. Tan DS, Marchio C, Jones RL, Savage K, Smith IE, Dowsett M, ReisFilho JS. Triple negative breast cancer: molecular profiling and prognostic impact in adjuvant anthracycline-treated patients. Breast Cancer Res Treat 2008; 111: 27-44.

25. Rakha EA, El-Sayed ME, Green AR, Lee AH, Robertson JF, Ellis IO. Prognostic markers in triple-negative breast cancer. Cancer 2007; 109: 25-32.

26. Bidard FC, Matthieu MC, Chollet P, Raoefils I, Abrial C, Domont J, Spielmann M, Delaloge S, Andre F, Penault-Llorca F. p53 status and efficacy of primary anthracyclines/alkylating agent-based regimen according to breast cancer molecular classes. Ann Oncol 2008; 19: 1261-5. 